\title{
Independent Learning Mode Innovation Teaching Reform Fundamentals of Electronics and Circuits
}

\author{
Rongxia Duan ${ }^{1, a}$ and Baocai $\mathrm{Xu}^{2, \mathrm{~b}}$ \\ ${ }^{1,2}$ Ordnance Engineering College, Shijiazhuang, China \\ a163595150@qq.com, b165007605@qq.com
}

Keywords: Autonomous learning; Practice innovation; Electronic and circuit basis

\begin{abstract}
The electronic circuit and is based on information and computer basic courses in undergraduate colleges class students, covering the circuit analysis, analog electronic technology and the content of the course of practice, technology and research, strong innovation characteristics, is an important basic course for the students to participate in extracurricular science and technology competition. The National Electronic Design Contest platform in this paper, the exploration and practice of teaching reform of autonomous learning, practice and innovation of the course, teaching content, teaching platform, practice innovation and construction of teachers "several aspects of teaching reform of electronic circuit and the basic course of exploration and practice, in order to improve the students' autonomous learning and practice and innovation ability, cultivate research and innovation ability.
\end{abstract}

\section{Introduction}

In the increasingly fierce international competition in the new century, the country needs to have independent learning, practice and innovation ability of comprehensive talents $[1,2]$. Therefore, the cultivation of autonomous learning, practice and innovation is becoming a hot spot in the world. As a college student, they have a certain ability of autonomous learning and independent thinking ability, especially the ability of the students now generally accept new things relatively strong, love excitement, the pursuit of novelty, active thinking, creative, good from various channels, especially to receive new information on the network, learning new things, with strong learning ability to accept. If we blindly follow the traditional mode of teaching, students have been in a passive state, it is inevitable that boring, so that they are not conducive to the absorption of new knowledge, it is not up to the expected effect of teaching. Therefore, it is necessary to introduce the idea of autonomous learning. As a teaching method, autonomous learning can effectively change the man Tangguan, cramming the traditional teaching mode, the teacher change from imparting knowledge to explore the knowledge navigator, make students change from passive learning to active learning, the classroom is changing from "Teacher centered" to "student center". However, due to the different knowledge of professional disciplines and students, in the implementation process, there are many problems to be solved [3]. The national electronic design contest and mathematical modeling contest platform in this paper. The exploration and practice of teaching reform of autonomous learning, practice and innovation of the course, teaching content, teaching platform, practice innovation and construction of teachers "and several aspects of electronic circuit" course teaching reform exploration and practice, in order to improve students' autonomous learning and innovation ability, cultivate research and innovation ability. 


\section{The Concept and Characteristics of Autonomous Learning}

The so-called autonomous learning refers to the students in the teachers' scientific guidance, through various means and channels, have a purpose, selection, active and creative learning activities, to achieve independent development, "the scientific guidance of teachers is a prerequisite and leading, students are the main body of students; the creative learning is the educational and teaching activities the center is a basic way of education and the way to realize the development of autonomy is the purpose of education and teaching activities, is the essence of all education activities required. The main characteristics of the autonomous learning model include the following aspects.

Initiative. Autonomous Learning in the premise of respect, trust and play to the initiative, so that students in the learning activities change "to me" to "I want to learn". Through active learning, has fundamentally changed the status of the students: From Heteronomy to self-discipline, from passive to active, from negative to positive. Not only develop the potential of students, but also cultivate students' sense of responsibility.

Independent. It is in the learning activities of students is in the form of "I can learn." "I can learn" is a kind of cognitive orientation based on the learning of students, for students to learning activities to get rid of dependence on teachers or others. Students have the right according to their ability and interests and establish their own learning objectives, learning methods and learning methods.

Innovative. Innovation means that each student is the main body of exploration, have the spirit of innovation. The ultimate goal of learning is to learn autonomous learning innovation, encourage students to learn creatively, such as learning to draw, have a rich imagination, dare to express different opinions with others, love to do some small production, small inventions, so as to cultivate students' innovative spirit and practical ability. This requires teachers to create conditions in the classroom teaching, guide students to think actively, and encourage them to dare to try, dare to challenge, inspire students' imagination, using different methods from different angles to solve the problem of.

Asynchronous. The new curriculum requires attention to each student's development, respect for individual differences of students autonomous learning, students according to their own needs, develop specific learning objectives, learning content related, and to learn the results to make a self assessment. Asynchronous learning makes excellent students ability and individuality talent shows itself, development; the basis of poor students can also be increased, under the guidance of the teacher and the help of the joy of harvest, and enhance self-confidence.

\section{To Create Autonomous Learning Mode Principle}

Clear Goals. Teachers should have a clear goal in constructing the mode of autonomous learning. For example, in order to improve the students' practical ability, or to cultivate students' innovative thinking, etc.. According to these different abilities, teachers can type, question type, explain type a variety of ways and means to ignite the enthusiasm of students through the heuristic, motivation, clear learning activities to promote students' positive thinking, active learning, absorb new knowledge constantly, consolidate the new knowledge, strengthen the effect of classroom teaching.

Set the Right Way. In the construction of autonomous learning mode, teachers should consciously set the way for students. The methods of promoting students' autonomous learning and stimulating students' potential can be varied. For example, exercises to consolidate the law, through the exercises set makes students to independent thinking, independent learning and exploring the 
way to find the answer, to consolidate the knowledge; guide method, through a series of problems for students to question, to produce a strong desire for knowledge, cultivate their awareness of the problem, they have to solve problems independently the habit of the game; incentive method, by setting up a series of targeted activities to motivate and train the students' practical application ability; with the method of grouping, prompting them to communicate with each other and talk to each other and learn from each other by the distribution of groups, give full play to complementary role between them.

Pay Attention to Communication, Assistance and Cooperation. In the construction of the mode of autonomous learning, in addition to actively guide students to develop the habit of independent thinking, independent learning, teachers should pay attention to communication with students, give full play to the role of student assistance and cooperation. The cultivation of students' autonomous learning ability is not equal to the teacher can go, laissez faire. Teachers should encourage students to make full use of this part of the extra-curricular time to carry out independent learning, and as much as possible to participate in, strengthen communication between teachers and students.

Make Full Use of Spare Time. We should make full use of the students' spare time in the construction of autonomous learning mode. Compared to high school, college students' extracurricular time is abundant, but most of the students are living in a confused state, most of the time they don't know what a large part of the decide on what path to follow, so precious in my spare time is very easy to be wasted if they can, this part of the rational use of time, then the self-regulated learning ability of the students will have can reach the ideal state.

\section{To Create Autonomous Learning Practice Research Mode}

Compulsory course and electronic circuit is based on the vehicle and the Department of electrical engineering, Ordnance Engineering College, covers the circuit analysis and Simulation of electronic technology, occupies a pivotal position in the undergraduate teaching of theories and experiments, the courses are important for students to participate in the National Undergraduate Electronic Design Contest and other extracurricular science and technology competition. This course has the characteristics of practicality, technology, research and innovation, and it is more suitable for the implementation of the reform of students' autonomous learning and practical innovation teaching mode.

Additional Electronic and Circuit Based Learner Autonomy. The teaching module based on electronic circuit based on the main teacher, take project driven, macro measures to instructional design ability training as the main line, set up autonomous learning and practice of teaching innovation in the course of the case, case base design including practical audio amplifier, simple light should be painted characters system, diode parameter tester, intelligent tracing electric and electronic calendar design, intelligent keyboard wireless remote control circuit, intelligent temperature alarm system. Students according to their own interest in the topic, after the topic of independent exploration and interactive collaborative learning. The students' autonomous learning activities are mainly composed of 5 parts: topic selection, literature review and learning, circuit design simulation and development, research report writing, general assembly report. In the process of autonomous learning, students as the main body, the teacher is only responsible for the direction of research and ideas, the use of heuristic, discussion, exploration and other teaching methods, try not to interfere with the students' learning activities. On the problems encountered, students can discuss with students or teachers, or in the teacher's inspiration and guidance to solve. At the end of the course requires students to report to the general assembly in the form to the other students to 
show their learning achievements, teachers, students through the evaluation summary form of feedback learning outcomes of students of curriculum knowledge understanding, analysis, and comparison with other professional courses mastery ability.

Construction of Teaching, Experiment and Enterprise Practice Base of Three-Dimensional Teaching Platform. In addition to traditional classroom learning and experiment, independent design and development of network teaching platform of the course of the project organization students, establish electronic teaching system, BBS learning BBS, database and Multisim circuit integrated practice innovation platform function module. Relying on the network teaching system, students can independently online learning, online discussion and exchange of experience with other students and faculty, convenient courses discussion, unit knowledge test, Download courseware multidimensional learning activities, teachers can answer questions online and released open operation, comprehensive operation, scientific research, will face "between teachers and students" Teaching and learning development for the teachers and students whenever and wherever possible the interaction between learning and research. The electronic circuit course is a basic course for students to participate in the national electronic design contest, but the electronic design contest title is put forward based on the practical problems in real life, practice field is broad, the actual case is rich, solving these problems are no precedent in textbooks and references, no ready-made method and process copy. Students are required to give a group of 3 to 4 days time to give solutions, such as the extracurricular science and technology competition for students to expand the basic knowledge in a short period of time, learn new knowledge and innovation to provide a platform for the 3 . This project is to organize and guide the students to participate in mathematical modeling and electronic design contest, through training, combat simulation, scientific writing training, competition, after the summary link, quickly find documents to upgrade their skills, fast learning ability and the application of new knowledge ability, multi-disciplinary, hard-working spirit and innovation ability group collaboration. This project organizes the students to participate in the practical project of the practice base outside the discipline.

Constructing the Practice Innovation Platform. In view of the relatively weak status of the electronic R \& D industry in Hebei Province, this paper puts forward the requirements for the cultivation of college students in learning and practice. Therefore, the project encourages students to participate in the company's electronic product development projects and teachers of scientific research projects. For example, let the students participate in the practice base, the R \& D project subject leaders in scientific research projects, let the company engineer or project manager of one or more specific sub problems, through access to information, students autonomous learning, group discussion, design, engineer or teacher guidance modification and improvement scheme, simulation and development other aspects involved in the development of practical electronic engineering projects, the cultivation of students' scientific research ability.

On the basis of certain scientific research ability, encourage students to expand the application or improvement of the scientific research topic in theory design, puts forward the subject of innovative research, teachers grasp the significance and feasibility of student groups to carry out research and encourage the reporting of school, provincial innovation experiment project, improve the students' scientific research ability and good teamwork spirit stimulate students' learning, electronic and computer theory course of interest, to promote other professional teaching virtuous circle. Publication of scientific research papers is an important way to show the results of innovative research, but students at the undergraduate level, do not have the ability to write professional papers and schools have not yet set up courses.

Therefore, in the course of the construction, encourage and guide the students to write scientific 
papers, summarize the innovation points of the extracurricular science and technology competition or research projects, and published research papers at home and abroad. First of all, let the students through English journals reading papers, autonomous learning format and contents of scientific writing arrangement, article structure and language expression after writing a scientific paper. Then, the use of spare time with a team of faculty's research writing skills and experience of overseas study, evaluation, on the modification, control, guide students published in English research papers, further stimulate students' enthusiasm to participate in scientific research.

Construction of Teaching Staff. To encourage young teachers to pursue a doctorate in the teaching, academic conferences and activities, teaching methods of famous universities at home and abroad of the electronic circuit and the basis course of extensive reference, let young teachers increase knowledge, broaden their horizons, improve the quality of teaching. On the base of electronic circuit course teaching team in the practice of the concept of modern education teaching, the scientific research cooperation learning. Encourage teachers to improve the quality of teaching in the course of teaching at the same time, to declare scientific research projects to enhance their scientific research ability. Scientific research is not limited to scientific research, but also to carry out the teaching of this course. Encourage teachers to cooperate with enterprises, joint research and development projects with enterprises, update professional knowledge, improve their practical ability to apply knowledge. The development of the teaching team, give full play to the role of academic leaders, help, with the role of the academic leaders of the scientific research projects after sub projects to guide students to carry out scientific research. Please set up counseling seminars for academic leaders of electronic design competition, enhance the teaching ability and the guidance level of young teachers contest, broaden academic field and research ideas of teachers, teaching, scientific research and teaching and research faculty to enhance the binding ability of the construction of a rational structure, high academic level and research ability of the teachers.

\section{The Autonomous Learning Mode Significance}

One is through the creation of students autonomous learning teaching content, students can change the way of learning, stimulate students' interest and initiative in learning, inspire students to think actively, guide students to learn autonomous learning; two is the practice base on the National Undergraduate Electronic Design Contest and the school, promote the students' comprehensive practical ability, to achieve superior performance in extracurricular science and technology competition three is to encourage students to participate in; course related research projects and business projects, improve the students' innovation ability in scientific research, published in the English research papers at home and abroad, a comprehensive study of the spirit and innovation ability training; four is through the exploration and practice of the project, improve the teaching ability of teachers and develop a set of effective theory and practice innovation of Comprehensive Talents Cultivation teaching system and teaching mode for other Engineering curriculum innovation teaching model to provide a useful reference.

\section{Conclusion}

In recent years, the teaching reform of autonomous learning, practice and innovation of Ordnance Engineering College Department of electrical engineering and vehicle electronic circuit and the basic course of practice, summarizes some experience, to participate in the National Electronic Design Contest in guiding students achieved excellent results; at the same time, also found some problems in teaching in the process, in the national electronic design competition in the 
award-winning ranking is not ideal. Therefore, to explore in the future teaching, to several aspects in the teaching content, teaching platform, practice innovation and construction of teachers to explore and practice the curriculum reform and the basic electronic circuit, in order to improve the students' autonomous learning and innovation ability, cultivate autonomous learning and practice of innovative talents.

\section{References}

[1] W.G Pang.Principles and Strategies of autonomous learning and teaching [M]. East China Normal University press, 2003. (In Chinese)

[2] G.Y Y.Construction of College Students' autonomous learning model based on SRL theory[J].Journal of Inner Mongolia Normal University(Education Science Edition.2016, 29(9). (In Chinese)

[3] R.Li,T.Dong.Research on cooperative learning model based on computer and network [J]. Journal of Hebei University,2006(4):126-129. (In Chinese)

[4] J.P.Li,W.Wei.Introduction to education[M].People's education press, 2000.(In Chinese)

[5] R.T.Yuan.Reflections on the teaching of autonomous learning [J]. Chinese School Sports,2003.1. (In Chinese)

[6] M.Q Li,X.M.She,Y.Y.Wu,X.Sun,G.Y.Zhang.A Practical Exploration of University Students' English Autonomous Learning Based on PBLL[J].Journal of Jilin Institute of Chemical Technology,2016,33(2). 